Original Article

\title{
Prevalence of cutaneous leishmaniasis in the largest populated city Karachi, Pakistan
}

\author{
Prevalência de leishmaniose cutânea na maior cidade populosa de Karachi, Paquistão
}

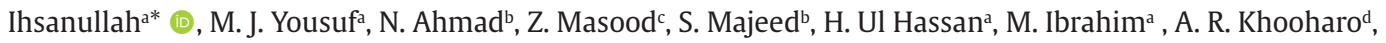
E. Khooharo ${ }^{\text {, A. H. Mastoif }}$, N. Zafarg and F. M. Shaikh ${ }^{g}$

aUniversity of Karachi, Department of Zoology, Karachi-75270, Pakistan

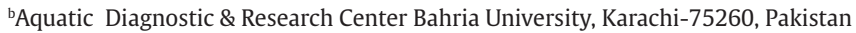

‘Department of Zoology, Sardar Bahadur Khan Women's University Quetta Balochistan, Pakistan

${ }^{\mathrm{d} C e n t r e}$ of Excellence in Marine Biology University of Karachi, Karachi-75270, Pakistan

eRegional Training Institute Karachi, Population Welfare Department Government of Sindh, Pakistan

fFaculty of Agriculture, Lasbela University of Agriculture, Water and Marine Science, Uthal Balochistan, Pakistan

gInstitute of Skin Diseases, Sindh, Karachi, Pakistan

\begin{abstract}
.
The study was undertaken from September 2018 to April 2019 to determine the prevalence of cutaneous leishmaniasis in human beings living in six districts of Karachi. Suspected persons were screened for the disease and positive cases were identified on the basis of skin lesions and blood samples. Samples were observed by mounting their smear. A total of 207 subjects of different ages and sex groups were investigated, however, only 192 (92\%) of the suspected cases were found to have the disease $64 \%$ of cases were male which were significantly high $(p<0.05)$, than female $36 \%$. The lesion was more frequently detected among the youth ages of $21-30$ years (31\%) as compared to other groups. In both sexes, legs were found to be more infected ( $25 \%$ male $+20 \%$ female) followed by arms ( $20 \%$ male $+0 \%$ female $)$ and face $(15 \%$ male $+11 \%$ female). The mixed body parts had shown the lowest infections such as ( $4 \%$ in males $+5 \%$ ) in females. In conclusion, the highest and lowest leishmaniasis infections were observed in District West (23\% male $+9 \%$ female) followed by District East ( $15 \%$ male $+7 \%$ female), District Malir ( $11 \%$ male $+4 \%$ female), District Central ( $7 \%$ male $+5 \%$ female), District Korangi ( $4 \%$ male $+7 \%$ female) and District South ( $4 \%$ male $+4 \%$ female) respectively.
\end{abstract}

Keywords: diagnosis, infectious disease, Leishmania, parasitic diseases, zoonosis.

\begin{abstract}
Resumo
O estudo foi realizado de setembro de 2018 a abril de 2019 para determinar a prevalência de leishmaniose tegumentar em seres humanos que vivem em seis distritos de Karachi. Pessoas suspeitas foram rastreadas para a doença e os casos positivos foram identificados com base em lesões de pele e amostras de sangue. As amostras foram observadas montando seu esfregaço. Um total de 207 indivíduos de diferentes idades e grupos sexuais foi investigado, no entanto apenas 192 (92\%) dos casos suspeitos foram encontrados para ter a doença; 64\% dos casos eram do sexo masculino, que foram significativamente elevados ( $<<0,05$ ), e do sexo feminino $36 \%$. A lesão foi detectada com maior frequência entre os jovens de 21 a 30 anos (31\%) em comparação com os outros grupos. Em ambos os sexos, as pernas estavam mais infectadas (25\% homens $+20 \%$ mulheres), seguidas pelos braços $(20 \%$ homens $+0 \%$ mulheres) e rosto ( $15 \%$ homens $+11 \%$ mulheres). As partes mistas do corpo mostraram as infecções mais baixas ( $4 \%$ homens $+5 \%$ mulheres). Em conclusão, as infecções de leishmaniose mais altas e mais baixas foram observadas no Distrito Oeste (23\% homens + 9\% mulheres) seguido pelo Distrito Leste ( $15 \%$ homens $+7 \%$ mulheres), Distrito Malir (11\% homens + 4\% mulheres), Distrito Central ( $7 \%$ homens + 5\% mulheres), Distrito Korangi (4\% homens $+7 \%$ mulheres) e Distrito Sul (4\% homens $+4 \%$ mulheres), respectivamente.
\end{abstract}

Palavras-chave: diagnóstico, doenças infecciosas, leishmania, doenças parasitárias, zoonoses.

\section{Introduction}

Cutaneous leishmaniasis is a vector born protozoan disease caused by a parasite Leishamania and transmits by the bite of a female sand fly. In humans, such parasites are extensive in endemic areas along with suitable sand- fly vectors and mostly found in immune suppressed individuals (Kimutai et al., 2017). Among Leishamania species, approximately 20 species are well-known with the potential of causing infections in humans. Three

*e-mail: ihsan.zoologist@gmail.com

Received: January 14, 2021 - Accepted: June 4, 2021

This is an Open Access article distributed under the terms of the Creative Commons Attribution License, which permits unrestricted use, distribution, and reproduction in any medium, provided the original work is properly cited. 
types of clinical infections are caused by these species which are visceral leishmaniasis (VL), mucocutaneous leishmaniasis (ML) and cutaneous leishmaniasis (CL) (Chaudhary et al., 2008).

WHO (2017) reported the most affected countries with Cutaneous Leishmaniasis including Pakistan, Afghanistan, Albania, Kuwait, Lebanon, Algeria, Argentina, Azerbaijan, Belize, Mali, Brazil, Bulgaria, Cameroon, Tunisia, China, Colombia, Egypt, Ethiopia, Spain, Malta, Sri Lanka, France, Georgia, Guatemala, India, Jordan, Kazakhstan, Kenya, Libya, Mexico, Morocco, Namibia, Niger, Nigeria, Oman, Peru, Portugal, Saudi Arabia, Senegal, Croatia Slovenia, Sudan, Tajikistan, Syrian Arab Republic, Taiwan Republic of China, Greece, Thailand, Iran, Iraq, Turkmenistan, Turkey, Costa Rica, United State of America and Yemen

Pakistan always faces a great threat of many skin diseases including leishmaniasis. Unfortunately, there was no authentic record of leishmaniasis in Pakistan before 1935 till a seismic eruption observed in Quetta (Kakarsulemankhel, 2004). The first record of it was from the northern mountainous region in 1996 (Hussain et al., 2017). Since then about 20,000 of the cases annually reported (Khan et al., 2016). The biggest outbreaks of 11,000 cases were reported from Sindh areas viz; Dadu and Larkana (Marco et al., 2006). Cutaneous leishmaniasis is wide-spread and most prevalent in almost all provinces of Pakistan (Marco et al., 2006; Hussain et al., 2017).

This disease frequently infects the poorest population of the globe (Alvar et al., 2012). The Eastern Mediterranean Region has a severe problem of Leishmaniasis (WHO, 2008). It is a globally vector born disease, noted in 88 countries: 16 are developed countries 72 are developing and 13 of them are among the least developed. About $90 \%$ of $C L$ cases were recorded in 7 countries viz; Syria, Saudi Arabia, Afghanistan, Algeria, Brazil, Iran and Peru. According to World Health Organization (WHO), nearby 1.2 billion individuals globally suffer from CL, and about 5-20 lac new cases are recognized annually (Vélez et al., 2009).

The increased prevalence of leishmaniasis throughout the world is mainly attributed to several man-made factors, including migration, deforestation, urbanization and immunosuppression (Assimina et al., 2008). WHO, 2010 reported that there are three species of cutaneous leishmaniasis found in Pakistan. Leishmania tropica cause Anthroponotic Cutaneous Leishmaniasis (ACL), Leishmania major and Leishmania infantum causes Zoonotic Cutaneous Leishmaniasis (ZCL) and Zoonotic Visceral Leishmaniasis (ZVL) respectively. The vector and reservoir of Leishmania tropica are Papatasi sergenti and human respectively. The vector of Leishmania major is Papatasi papatasi, Papatasi salehi and reservoir are Indian desert gerbil (Meriones hurrianae), Great gerbil (Rhombomys opimus), while Leishmania infantum has unknown vector and their reservoir is dog.

Cutaneous leishmaniasis prevails nearly from Karachi, of Pakistan right from KPK to FATA, Punjab, Sindh and Baluchistan (Ayaz et al., 2018; Hussain et al., 2018; Sharif et al., 2017; Khan et al., 2016; Ul Bari et al., 2016; Ullah et al., 2016; Bhutto et al., 2016; Jamal et al., 2013; Durrani, 2011; Bhutto et al., 2009; Ullah et al., 2009; Kakarsulemankhel, 2004, Bhutto et al., 2003). The present investigation is specified to record the prevalence of cutaneous leishmaniasis and their therapeutics in six districts of Karachi, which is one of the largest cosmopolitan city of the World.

\section{Materials and Methods}

This study was conducted at the Department of Zoology, University of Karachi to record the prevalence of cutaneous leishmaniasis and their therapeutics in six districts of Karachi, Sindh Pakistan. The study was ethically approved from three hospitals in Karachi, Institute of Skin Disease, Karachi (ISDK), Jinnah Postgraduate Medical Centre (JPMC) and Civil Hospital Karachi. A total of 207 suspected patients visiting regularly to the ISDK with active lesions were examined clinically. A pre-designed proforma was used to fill the information regarding name, father's name, sex, age, profession, site of lesions, number of lesions, Date of the appearance of the first signs of the disease, previous history, address, ethnic origin, treatment, previous diagnosis through microscopic examination and or biopsy test, other family affected etc. Data regarding different variables were obtained through face-to-face interview with the patient. Photographs of the lesion were taken using a digital camera of mobile phone.

\subsection{Statistical analysis}

For statistical analysis Microsoft Office Excel Package 2007® was used. The Student T-test was applied for significant differences. Where significant differences among male, females, age wise, infected body parts and areas wise the significance level was at $p<0.05$.

\subsection{Collection of blood and skin biopsy samples}

\subsubsection{Biopsy samples}

Skin lesion samples were collected with clinical signs of skin infection. Before collection, the skin lesions were cleaned and sterilized with $100 \%$ ethanol. The lesions were punctured in between thumb and forefinger. Skin-scrap samples were taken from the punctured border of the lesion using a sterile blood lancet and placed on one side of the slide. A thick smear on one side of the examination slide was made and fixed in $100 \%$ methanol for 30 minutes. The slides were marked with a serial number using a permanent marker.

\subsubsection{Blood samples}

Peripheral blood was taken through a syringe and gently put into the test tube. The obtained blood samples were centrifuged (3000 rpm) for 30 minutes. The Buffy coat was taken through a pipette and made a thin layer on the examination slides and fixed in $100 \%$ methanol for 30 minutes. After staining the slides were gently washed with water and air-dried and ready for histopathology.

\subsubsection{Staining and diagnosis by microscopy}

Cutaneous leishmaniasis can easily be diagnosed by direct observation of parasite in impression smears, skin biopsies stained with giemsa stain (Sundar and Benjamin, 
2003). Dry, thin fixed slides of blood and skin lesions from infested patients were dipped in working Giemsa stain for 30 minutes in a staining jar. After staining the slides were air-dried and washed gently with water and again air-dried. The slides were observed under the oil immersion objective (10 x 100 magnifications) for identification of protozoan parasite; (Leishman Donovan bodies) using a microscope. Detection of Leishman-Donovan (LD) bodies in the smear was considered as a positive case.

\section{Results}

From September 2018 to April 2019 a study was conducted to determine the prevalence of cutaneous leishmaniasis amongst 207 residents in six districts of the Karachi city. A total of 207 people were searched in the study, 192 of the person, case (92.75\%) were found having Cutaneous leishmaniasis, including $64 \%$ males $(n=123)$ and $36 \%(n=69)$ females. Their age range was from 0 to 70 years ( 0 means from the first day of birth to one year). The highest frequency of Cutaneous leishmaniasis was noted as $31 \%$ in the age group $21-30$ years, followed by $22 \%$ ( $11-20$ years), 20\% (0-10 years), 13\% (3140 years) and the lowest prevalence rate was recorded as $7 \%$ in both the age group 41-50 and 51-60 years. Exposed body parts of both sexes were heavily found infected. The highest percent infections were observed on the legs $(24.8 \%$ male $+19.8 \%$ female) followed by arms ( $20 \%$ male $+0 \%$ female), face ( $15.3 \%$ male, $+10.9 \%$ female) and the mixed body parts had shown the lowest infections ( $4.4 \%$ male $+4.8 \%$ female). As for as the area-wise incidence of Cutaneous leishmaniasis is concerned the samples from District West of Karachi city area indicated the highest prevalence rate $(23.2 \%$ male $+8.8 \%$ female) followed by District East ( $14.6 \%$ male $+7.4 \%$ female),
District Malir (10.7\% male+ 4.3\% female), District Central (6.8\% male $+5.2 \%$ female), District Korangi $(4.4 \%$ male $+6.6 \%$ female) and District South (3.8\% male + 4.2\% female) (Table. 1 ).

The statistical data reveals that gender wise significant difference were noted in male and female, the males are infected significantly high $(p<0.05)$ as compared to the females. Age wise there is no significant difference $(p>0.05)$ in the age group between 0 to 10,11 to 20,31 to 40,41 to 50,51 to 60 and 61 to 70 years, but a significant difference $(p<0.05)$ was found in the age group 21 to 30 years. In body parts (face, legs and mixed) both male and females are significantly same, but arms are significantly high $(p<0.05)$ in male than females. If we compared area wise district West were significantly higher $(p<0.05)$ than rest of others five districts of Karachi (Table. 1).

The overall prevalence of Cutaneous leishmaniasis was found including $68 \%(n=141)$ males and 32\% ( $n=66)$ females. The highest frequency of the disease was noted as $24 \%$ in the age group $0-10$ years, followed by $23 \%$ (21-30), $17 \%$ in both (11-20 and 31-40), 9\% (41-50 years), and the lowest incidence rate was recorded as $5 \%$ in both age groups 51-60 and 61-70 years. Exposed body parts of both sexes were heavily found infected. The highest percent of infections were observed on the face $(16 \%$ male $+13 \%$ female) followed by arms ( $19 \%$ male $+7 \%$ female), legs ( $18 \%$ male, $+7 \%$ female) and the mixed body parts had shown the lowest infections ( $15 \%$ male $+5 \%$ female). As for as the area-wise incidence of Cutaneous leishmaniasis is concerned the samples from Baluchistan indicated the highest prevalence rate (34\% male $+11 \%$ female) followed by Sindh ( $20 \%$ male $+6 \%$ female), Khyber Pakhtunkhwa (15\% male+ 6\% female) and Punjab ( $4 \%$ male $+4 \%$ female). (Figure 1 )

The majority of the lesions were observed on the exposed body parts (Figure 2). Further, the infection

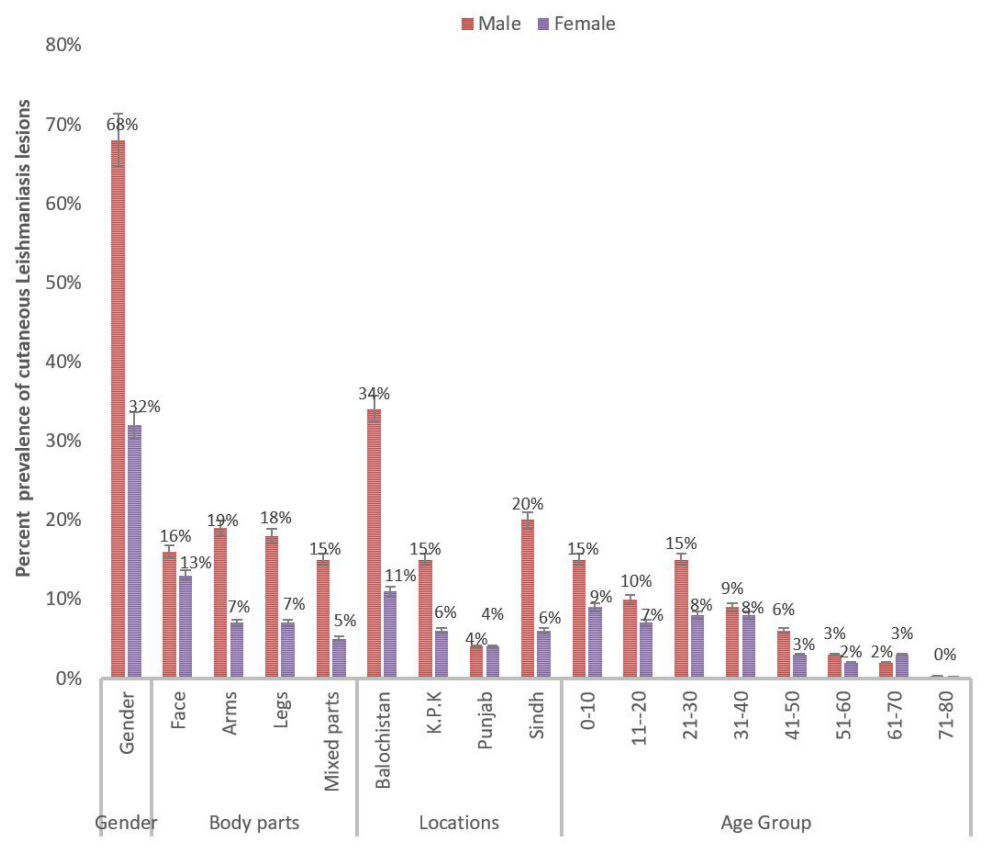

Figure 1. Percentage prevalence of cutaneous Leishmaniasis in body parts of both genders along with age group in various provinces of Pakistan. 
was more prevalent in younger persons as compared to children and older people and almost every district of the city was found to have the patients reported for cutaneous leishmaniasis (Table 1, Figure 1 and 2).
All the patients had lesions generally on uncovered parts of the body like hands, face, ankle, arm, ear and legs. The number of lesions on each patient was varying from one

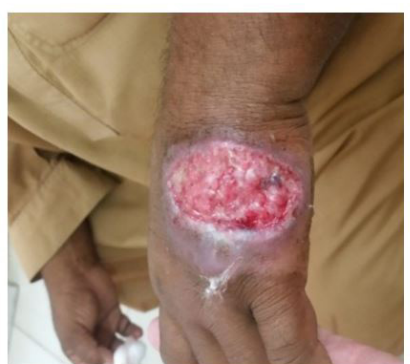

A

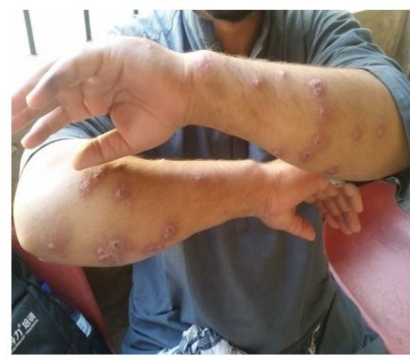

D

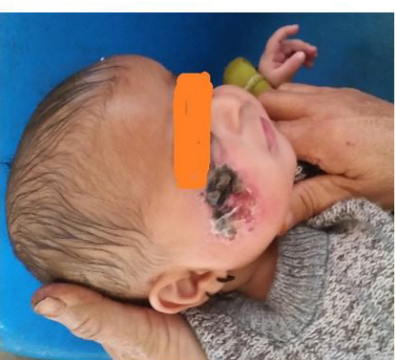

$\mathrm{B}$

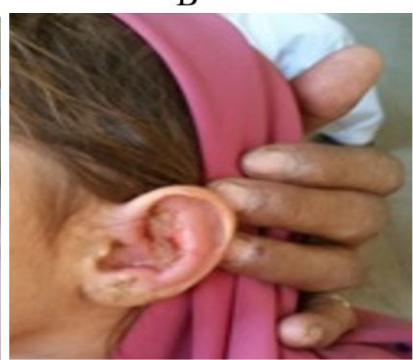

E

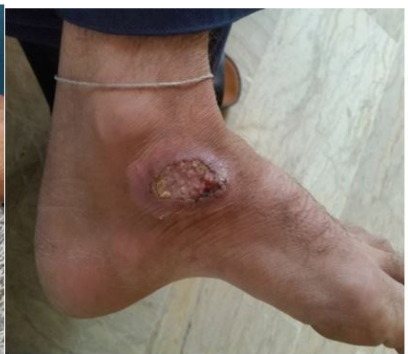

C

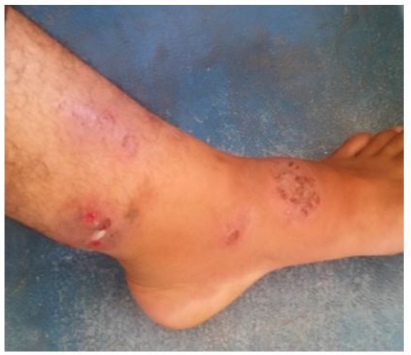

F

Figure 2. Infected body parts; $A=$ hand; $B=$ face; $C=$ ankle; $D=\operatorname{arm} ; E=$ ear; $F=$ leg.

Table 1. Prevalence of Cutaneous Leishmaniasis in Gender, Body parts, Age and area wise in Karachi, Pakistan.

\begin{tabular}{|c|c|c|c|c|c|}
\hline \multicolumn{6}{|c|}{ Gender Wise Leishmaniasis } \\
\hline Gender & Male & Female & Total & Male Percent & Female Percent \\
\hline No of Patient & $35^{\mathrm{a}}$ & $20^{\mathrm{b}}$ & 55 & $64 \%$ & $36 \%$ \\
\hline \multicolumn{6}{|c|}{ Age Wise Leishmaniasis } \\
\hline Age & Male & Female & Total & Male Percent & Female Percent \\
\hline $0-10$ & $6^{\mathrm{a}}$ & $5^{\mathrm{a}}$ & 11 & $11 \%$ & $9 \%$ \\
\hline $11-20$ & $7^{\text {a }}$ & $5^{a}$ & 12 & $13 \%$ & $9 \%$ \\
\hline $21-30$ & $13^{\text {a }}$ & $4^{b}$ & 17 & $24 \%$ & $7 \%$ \\
\hline $31-40$ & $5^{\text {a }}$ & $2^{a}$ & 7 & $9 \%$ & $4 \%$ \\
\hline $41-50$ & $1^{\text {a }}$ & $3^{a}$ & 4 & $2 \%$ & $5 \%$ \\
\hline $51-60$ & $3^{a}$ & $1^{\text {a }}$ & 4 & $5 \%$ & $2 \%$ \\
\hline $61-70$ & $0^{\text {a }}$ & $0^{\text {a }}$ & 0 & $0 \%$ & $0 \%$ \\
\hline \multicolumn{6}{|c|}{ Body Parts Wise Leishmaniasis } \\
\hline Body Parts & Male & Female & Total & Male Percent & Female Percent \\
\hline Face & $8^{a}$ & $6^{\mathrm{a}}$ & 14 & $15 \%$ & $11 \%$ \\
\hline Arms & $11^{\mathrm{a}}$ & $0^{\mathrm{b}}$ & 11 & $20 \%$ & $0 \%$ \\
\hline Legs & $14^{\mathrm{a}}$ & $11^{\mathrm{a}}$ & 25 & $25 \%$ & $20 \%$ \\
\hline Mixed & $2^{\mathrm{a}}$ & $3^{a}$ & 5 & $4 \%$ & $5 \%$ \\
\hline \multicolumn{6}{|c|}{ Area Wise Leishmaniasis } \\
\hline Area & Male & Female & Total & Male Percent & Female Percent \\
\hline District East & $8^{a}$ & $4^{\mathrm{a}}$ & 12 & $15 \%$ & $7 \%$ \\
\hline District West & $13^{\mathrm{a}}$ & $5^{\mathrm{b}}$ & 18 & $23 \%$ & $9 \%$ \\
\hline District South & $2^{\mathrm{a}}$ & $2^{a}$ & 4 & $4 \%$ & $4 \%$ \\
\hline District Central & $4^{\text {a }}$ & $3^{\mathrm{a}}$ & 7 & $7 \%$ & $5 \%$ \\
\hline District Malir & $6^{a}$ & $2^{\mathrm{a}}$ & 8 & $11 \%$ & $4 \%$ \\
\hline District Korangi & $2^{a}$ & $4^{a}$ & 6 & $4 \%$ & $7 \%$ \\
\hline
\end{tabular}

Values (male, female, age wise, infected body parts and area wise of all patients a, b. are significantly different $(p<0.05$ ) from each other. 
to eight (1-8) and only one patient had approximately thirty (30) ulcerative lesions on legs, arms and face (Figure 2d).

\section{Discussion}

The leishmaniasis is endemic in many parts of the world involving the tropical countries. Asian communities are mostly comprised of the individuals of poor localities having sub-standard living styles. Vector born diseases are more common among such individuals. According to (Durrani, 2011) leishmaniasis, prevails not only in Pakistan but also in India, Iran, Afghanistan and China.

According to the literature cited, the extensive studies on leishmaniasis has been reported in Pakistan from 2003 to 2018 (Ayaz et al., 2018; Hussain et al., 2018; Sharif et al., 2017; Khan et al., 2016; Ul Bari et al., 2016; Ullah et al., 2016; Bhutto et al., 2016; Jamal et al., 2013; Durrani, 2011, Bhutto et al., 2009; Ullah et al., 2009; Kakarsulemankhel, 2004).

Ullah et al., 2009, reported from North West Frontier Province (NWFP) a number of cases of Cutaneous leishmaniasis in individuals of 1-15 years of age than the older age of people. Similarly, they reported that the disease is more prevalent among males (60.5\%) than in females (39.5\%). This report of (Ullah et al., 2009) is in line with the present investigation, as we observed (among 207 of the cases studied) $64 \%$ were of the male cases and $36 \%$ of female. The lapse of ten years between the previous and the present report shows the constancy of cutaneous leishmaniasis in Pakistan. This gender difference may be due to the reason of the female confinement to their homes while males usually have outside exposure to fulfil their job requirement and business purpose. Another study by (Rahman and Rehman, 2018) from Lower Dir, Pakistan indicated a significant difference between male and female incidents due to cutaneous leishmaniasis. In males 24.5\% infection was diagnosed while the female has only $16.1 \%$ of the infection as an important skin disease. However an earlier report of (Bhutto et al., 2009) indicated a slight difference between male and female cases. They actually assessed the whole country and found Baluchistan and Sindh provinces are mainly affected due to this disease. According to them the huge number of cases is from Sindh province. The diagnostic procedure was the same as we followed in the present research investigation that is by smear test and examining skin lesions.

Cutaneous leishmaniasis is recently reported a neglected tropical disease (Ayaz et al., 2018) while assessing the cases of Cutaneous leishmaniasis in Multan (a city of Punjab province). They reported 198 Cutaneous leishmaniasis positive patients ranged in age 10-40 years old where 101 were males and 97 were females. In the present case skin lesions pertaining to Cutaneous leishmaniasis were frequently diagnosed in individuals ranged in between 21-30 years. A slight difference with reference to gender and age distribution may be due to environmental differences between the two provinces. Moreover, in the present investigation $32 \%$ of the positive cases were noted from district West only, due to overcrowded in population while just $8 \%$ from district South.
Sindh province always remains targeted from leishmaniasis. A survey done by (Sharif et al., 2017) from all over Pakistan reported 94 patients positive to the disease from Sindh province. They collected the data of 102 patients covering each province of Pakistan. By sighting the literature, there remains no doubt for having leishmaniasis as one of the major skin diseases in Sindh. It is spreading widely and dramatically.

We suggest here to control its vector by spraying from some non-conventional pesticides, especially from last week of August up to December as the adult flies during this period are numerous on their breeding grounds.

\section{Conclusion}

Karachi from the last few years threatened by many epidemics such as Congo fever and Dengue fever, this report shows the current status of a protozoan disease (Cutaneous leishmaniasis) in addition to the above viral fevers in just a few months of the year.

The disease can only be controlled by controlling its potential vector. In Karachi straying dogs seem to have lesions in their neck and belly areas, dogs should also be undertaken as a subject to probe the (Cutaneous leishmaniasis) cases in dogs which may be a source of Cutaneous leishmaniasis transmission to man.

\section{References}

ALVAR, J., BERN, C., HERRERO, M. and CANO, J., 2012. Leishmaniasis worldwide and global estimates of its incidence. PLoS One, vol. 7, no. 5, e35671.

ASSIMINA, Z., CHARILAOS, K. and FOTOULA, B., 2008. Leishmaniasis: an overlooked public health concern. Health Science Journal, vol. 2, no. 4, pp. 196-205.

AYAZ, M.M., NAZIR, M.M., ULLAH, N., ZAMAN, A., AKBAR, A., ZEESHAN, M., HUSSAIN, Z., NAZ, S., ZHENG, Y., JAVED, A. and LINDSAY, D.S., 2018. Cutaneous leishmaniasis in the Metropolitan City of Multan, Pakistan, a neglected tropical disease. Journal of Medical Entomology, vol. 55, no. 4, pp. 1040-1042. http:// dx.doi.org/10.1093/jme/tjy003. PMid:29415246.

BHUTTO, A.M., SOOMRO, F.R. and KATAKURA, K., 2016. Leishmaniasis in Sindh, Pakistan: outbreak and review of the literature. Journal of Pakistan Association of Dermatologists, vol. 18, no. 4, pp. 212-219.

BHUTTO, A.M., SOOMRO, F.R., BALOCH, J.H., MATSUMOTO, J., UEZATO, H., HASHIGUCHI, Y. and KATAKURA, K., 2009. Cutaneous leishmaniasis caused by Leishmania (L.) major infection in Sindh province, Pakistan. Acta Tropica, vol. 111, no. 3, pp. 295-298. http://dx.doi.org/10.1016/j.actatropica.2009.05.009. PMid: 19467219.

BHUTTO, A.M., SOOMRO, R.A., NONAKA, S. and HASHIGUCHI, Y., 2003. Detection of new endemic areas of cutaneous leishmaniasis in Pakistan: a 6-year study. International Journal of Dermatology, vol. 42, no. 7, pp. 543-548. http://dx.doi. org/10.1046/j.1365-4362.2003.01818.x. PMid:12839604.

CHAUDHARY, R.G., BILIMORIA, F.E. and KATARE, S.K., 2008. Diffuse cutaneous leishmaniasis: co-infection with human immunodeficiency virus (HIV). Indian Journal of Dermatology, Venereology and Leprology, vol. 74, no. 6, pp. 641-643. http:// dx.doi.org/10.4103/0378-6323.45111. PMid:19171992. 
DURRANI, A.Z., 2011. Prevalence of cutaneous leishmaniasis in humans and dogs in Pakistan. Pakistan Journal of Zoology, vol. 43, no. 2, pp. 263-271.

HUSSAIN, M., MUNIR, S., AYAZ, S., KHATTAK, B.U., KHAN, T.A., MUHAMMAD, N., ANEES, M., RAHMAN, H., QASIM, M., JAMAL, M.A., AHMED, I., RAHIM, K., MAZHAR, H., WATANAY, N. and KASBARI, M., 2017. First report on molecular characterization of Leishmania species from cutaneous leishmaniasis patients in southern Khyber Pakhtunkhwa province of Pakistan. Asian Pacific Journal of Tropical Medicine, vol. 10, no. 7, pp. 718-721. http://dx.doi.org/10.1016/j.apjtm.2017.07.015. PMid:28870350.

HUSSAIN, M., MUNIR, S., KHAN, T.A., KHAN, A., AYAZ, S., JAMAL, M.A., AHMED, I., AZIZ, S., WATANY, N. and KASBARI, M., 2018. Epidemiology of cutaneous leishmaniasis outbreak, Waziristan, Pakistan. Emerging Infectious Diseases, vol. 24, no. 1, pp. 159-161. http://dx.doi.org/10.3201/eid2401.170358. PMid:29260674.

JAMAL, Q., SHAH, A., ALI, N., ASHRAF, M., AWAN, M.M. and LEE, C.M., 2013. Prevalence and comparative analysis of cutaneous leishmaniasis in Dargai Region in Pakistan. Pakistan Journal of Zoology, vol. 45, no. 2, pp. 537-541.

KAKARSULEMANKHEL, J.K., 2004. Present situation of cutaneous leishmaniasis in Baluchistan, Pakistan. Pakistan Journal of Biological Sciences, vol. 7, no. 5, pp. 698-702.

KHAN, N.H., BARI, A., HASHIM, R., KHAN, I., MUNEER, A., SHAH, A., WAHID, S., YARDLEY, V., O'NEIL, B. and SUTHERLAND, C.J., 2016. Cutaneous leishmaniasis in Khyber Pakhtunkhwa province of Pakistan: clinical diversity and species-level diagnosis. The American Journal of Tropical Medicine and Hygiene, vol. 95, no. 5, pp. 11061114. http://dx.doi.org/10.4269/ajtmh.16-0343. PMid:27601518.

KIMUTAI, R., MUSA, A.M., NJOROGE, S., OMOLLO, R., ALVES, F., HAILU, A., KHALIL, E.A., DIRO, E., SOIPEI, P., MUSA, B., SALMAN, K., RITMEIJER, K., CHAPPUIS, F., RASHID, J., MOHAMMED, R. JAMENEH, A., MAKONNEN, E., OLOBO, J., OKELLO, L., SAGAKI, P., STRUB, N., ELLIS, S., ALVAR, J., BALASEGARAM, M., ALIROL, E. and WASUNNA, M., 2017. Safety and effectiveness of sodium stibogluconate and paromomycin combination for the treatment of visceral leishmaniasis in eastern Africa: results from a pharmacovigilance programme. Clinical Drug Investigation, vol. 37, no. 3, pp. 259-272. http://dx.doi.org/10.1007/s40261016-0481-0. PMid:28066878.

MARCO, J.D., BHUTTO, A.M., SOOMRO, F.R., BALOCH, J.H., BARROSO, P.A., KATO, H., UEZATO, H., KATAKURA, K., KORENAGA, M., NONAKA, S., and HASHIGUCHI, Y., 2006. Multilocus enzyme electrophoresis and cytochrome b gene sequencing-based identification of Leishmania isolates from different foci of cutaneous leishmaniasis in Pakistan. The American Journal of Tropical Medicine and Hygiene, vol. 75, no. 2, pp. 261-266. http://dx.doi.org/10.4269/ajtmh.2006.75.261. PMid:16896129.

RAHMAN, H.U. and REHMAN, A.U., 2018. Cutaneous leishmaniasis in Dir Lower District, North-West Pakistan: epidemiology and treatment response. Journal of Pakistan Association of Dermatologists, vol. 27, no. 4, pp. 353-362.

SHARIF, F., AHMAD, I. and GHAZI, R.R., 2017. Human cutaneous leishmaniasis in three districts of Sindh in Pakistan. Journal of Basic and Applied Sciences, vol. 13, pp. 611-615. http://dx.doi. org/10.6000/1927-5129.2017.13.98.

SUNDAR, S. and BENJAMIN, B. 2003. Diagnosis and treatment of Indian visceral leishmaniasis. JAPI, vol. 51, pp. 195-201.

UL BARI, A., HASSHIM, R., MAHMOOD, K., MUHAMMAD, I., SHAHBAZ, N. and TARIQ, K.M., 2016. Clinico-epidemiological pattern of cutaneous leishmaniasis in armed forces personnel fighting war against terrorism in Khyber Pakhtunkhwa Province and Fata regions. Journal of Pakistan Association of Dermatologists, vol. 21, no. 1, pp. 10-15.

ULLAH, K., KHAN, N.H., SEPÚLVEDA, N., MUNIR, A. and WAHID, S., 2016. Assessing incidence patterns and risk factors for cutaneous leishmaniasis in Peshawar region, Khyber Pakhtunkhwa, Pakistan. The Journal of Parasitology, vol. 102, no. 5, pp. 501-507. http://dx.doi.org/10.1645/15-919. PMid:27310301.

ULLAH, S., JAN, A.H., WAZIR, S.M. and ALI, N., 2009. Prevalence of cutaneous leishmaniasis in Lower Dir District (NWFP), Pakistan. Journal of Pakistan Association of Dermatologists, vol. 19, pp. 212-215

VÉLEZ, I.D., COLMENARES, L.M. and MUÑOZ, C.A., 2009. Two cases of visceral leishmaniasis in Colombia resistant to meglumine antimonial treatment. Revista do Instituto de Medicina Tropical de São Paulo, vol. 51, no. 4, pp. 231-236. http://dx.doi.org/10.1590/ S0036-46652009000400011. PMid:19739006.

WORLD HEALTH ORGANIZATION - WHO. 2008 [viewed 14 Jan 2021]. Report of the consultative meeting on cutaneous leishmaniasis [online]. Geneva: WHO. Available from: http://www. who. int/leishmaniasis/resources/Cutaneous_leish_cm_2008.pdf.

WORLD HEALTH ORGANIZATION - WHO. 2010. Report of a meeting of the WHO Expert Committee on the Control of Leishmaniases. Geneva: WHO.

WORLD HEALTH ORGANIZATION - WHO.. 2017 [viewed 14 Jan 2021]. Status of endemicity of cutaneous leishmaniasis Data by country, Global Health Observatory data repository [online]. WHO. Available from: http://www.who.int/gho/data/node. main.NTDLEISHCEND?lang=en 